\title{
Animal Studies in Spinal Cord Injury: A Systematic Review of Methylprednisolone
}

\author{
Aysha Z. Akhtar, John J. Pippin and Chad B. Sandusky \\ Physicians Committee for Responsible Medicine, Washington, DC, USA
}

\begin{abstract}
Summary - The objective of this study was to examine whether animal studies can reliably be used to determine the usefulness of methylprednisolone (MP) and other treatments for acute spinal cord injury $(\mathrm{SCl})$ in humans. This was achieved by performing a systematic review of animal studies on the effects of MP administration on the functional outcome of acute $\mathrm{SCl}$. Data were extracted from the published articles relating to: outcome; MP dosing regimen; species/strain; number of animals; methodological quality; type of injury induction; use of anaesthesia; functional scale used; and duration of follow-up. Subgroup analyses were performed, based on species or strain, injury method, MP dosing regimen, functional outcome measured, and methodological quality. Sixty-two studies were included, which involved a wide variety of animal species and strains. Overall, beneficial effects of MP administration were obtained in 34\% of the studies, no effects in 58\%, and mixed results in $8 \%$. The results were inconsistent both among and within species, even when attempts were made to detect any patterns in the results through subgroup analyses. The results of this study demonstrate the barriers to the accurate prediction from animal studies of the effectiveness of MP in the treatment of acute $\mathrm{SCl}$ in humans. This underscores the need for the development and implementation of validated testing methods.
\end{abstract}

Key words: animal, methylprednisolone, steroid, spinal cord injury.

Address for correspondence: A. Akhtar, Oxford Centre for Animal Ethics, 91 Iffley Road, Oxford OX4 $1 E G$, United Kingdom.

E-mail: aysha.akhtar@oxfordanimalethics.com

\section{Introduction}

While animal studies are conducted, in part, to inform human clinical care, several recent reviews have suggested a number of limitations of animal studies that impede the prediction of human outcomes (1-5). These limitations include deficient methodology, lack of standardisation, poor correlation of outcomes with those of clinical studies, and publication bias.

Multiple neuroprotective agents for the treatment of spinal cord injury (SCI) have yielded encouraging results in animal studies, but disappointing results in clinical trials. These disappointing results illustrate translational difficulties in drug testing for SCI treatment. Methylprednisolone (MP) is currently the only neuroprotective agent routinely used clinically for the treatment of acute SCI. The rationale for this intervention, and the recommended dosing regimen, were derived from the National Acute Spinal Cord Injury Study (NASCIS) 2 and 3 trials (6-7). Yet the effectiveness of MP remains in dispute, due to critical subsequent analysis (8-12). Due to limitations and gaps in data from the NASCIS trials, there is no clear consensus on the success rate of the treatment (13).

Perhaps because of the lack of consensus, extensive animal studies were performed to evaluate the effectiveness of MP, both before and after the
NASCIS trials, as guides for human intervention. Animal models for assessing MP for the treatment of SCI present a good test case for assessing the merits of animal-based approaches, due to the high number of animal studies and wide variety of animal models and species used. We chose MP a priori, because it has been the focus of more animal studies of acute SCI than any other potential neuroprotective agent. In this review, we investigated whether, and to what extent, poor methodological quality and lack of standardisation contribute to difficulties in translating animal research results to clinical use. We also investigated whether, and if so how, other factors such as inter-species and inter-strain differences might contribute to these difficulties. We attempted to address the following two questions: 1) Are there limitations to the animal models and studies, and if so, what are they?; and 2) Can we reliably use the animal models and studies to inform human intervention in acute SCI?

\section{Methods}

\section{Study identification}

The literature search was restricted to the published results of animal studies. Studies were 
included if they assessed and reported the effects of MP for the treatment of acute SCI in live animals. The exclusion criteria were as follows: a) the language was other than English; b) MP was combined with other treatments, or not directly compared with placebo; c) MP was administered prior to SCI induction, or SCI was non-traumatic (exischaemic SCI); d) only outcomes other than functional recovery were assessed; and e) the study was a duplicate or review of a prior study.

Relevant articles were identified from MEDLINE (PubMed), by using the search terms "methylprednisolone OR glucocorticoid OR steroid" AND "SCI OR spinal cord trauma OR spinal cord injury OR spinal cord". In cases of uncertainty or absence of abstracts, the full articles were reviewed. Reference lists from retrieved articles and from other relevant review articles were searched for additional studies.

\section{Data abstraction}

We abstracted the following data from each included study: a) the species and strain (when provided) used; b) the method of injury; c) the dose, timing and duration of MP administration; and d) the type of anaesthesia used during injury induction. Outcome data included: a) the number of animals used for outcome assessment; b) the specific clinical outcome assessed (functional scale used); and c) the duration of any follow-up.

\section{Outcome assessment}

For each study, we identified whether beneficial effects (statistically favouring MP treatment) or no effects (statistically not favouring MP treatment) were found. When functional tests were performed at different times, only the final test was included. In cases where no statistics were provided, we reported the original authors' conclusions. In cases of uncertainty, attempts were made to contact the authors for clarification.

\section{Subgroup assessment}

During our literature search, we noted substantial variability among studies, such as the dosing and timing regimen of $\mathrm{MP}$, the species and strains used, and duration of MP treatment and follow-up. We therefore prospectively identified the following subgroups for review: a) studies using the same species or strain; b) studies of $\geq$ four weeks (28 days) duration; c) studies using the same injury method (e.g. compression, contusion, or transection); and d) studies that followed a dosing regimen most similar to that currently used in humans
$(30 \mathrm{mg} / \mathrm{kg}$ i.v. within eight hours, then $5.4 \mathrm{mg} / \mathrm{kg} / \mathrm{hr}$ for 24-48 hours total; 6, 7).

After data collection, we noted that many studies involved a single MP dose of $30 \mathrm{mg} / \mathrm{kg}$, given i.v., either within five minutes of injury or at one hour post-injury. We therefore performed a post hoc review, comparing all studies employing either of these regimens. We also performed a post hoc review of the following subgroups of studies: a) those that administered MP within one hour and used either the Basso, Beattie, Bresnahan (BBB) locomotor test, the Rivlin and Tator inclined plane test or the Tarlov open field test to assess function (since these functional tests were most consistently used in the studies); and b) those studies that reported both blinding and randomisation, and with a duration of at least four weeks.

\section{Quality assessment}

To assess methodological rigour (14-16), we also assessed the data for each study for the following: a) randomisation of intervention; b) blinding of intervention and outcome measurements; c) monitoring and reporting of physiological parameters during injury induction; and d) reporting of housing and handling procedures.

Physiological parameters were defined as pulse, temperature, blood pressure, ECG, haematocrit (Hct), blood gas $\left(\mathrm{pO}_{2}, \mathrm{pCO}_{2}\right)$ and $\mathrm{pH}$, and glucose level. We rated the reporting of physiological parameters on the following scale: $\mathrm{N}=$ information not stated; $\mathrm{P}$ (Poor) = one parameter reported; $\mathrm{F}$ $($ Fair $)=$ two parameters reported; $G($ Good $)=$ three or more parameters reported.

Housing and handling procedures included: number of animals per cage, water and food provisions, ambient lighting, ambient temperature, environmental enrichment, bladder care, and number and type of handlings per day. We rated the reporting of housing and handling procedures on the following scale: $\mathrm{N}=$ information not stated; $\mathrm{P}($ Poor $)=$ one procedure or condition reported; $\mathrm{F}$ (Fair) $=$ three or more procedures or conditions reported; $\mathrm{G}(\mathrm{Good})=$ detailed information provided on three or more procedures or conditions.

\section{Results}

\section{Description of the studies}

The flowchart outlined in Figure 1 displays the search and article retrieval procedure. Sixty-two studies matched the inclusion criteria and are listed in Table 1 (17-78). A variety of methods, forces, weights, and heights were used to induce injury. SCI ranged from mild to severe, based on 
Figure 1: Search and article retrieval procedure

3293 potentially-relevant citations identified and screened for retrieval.

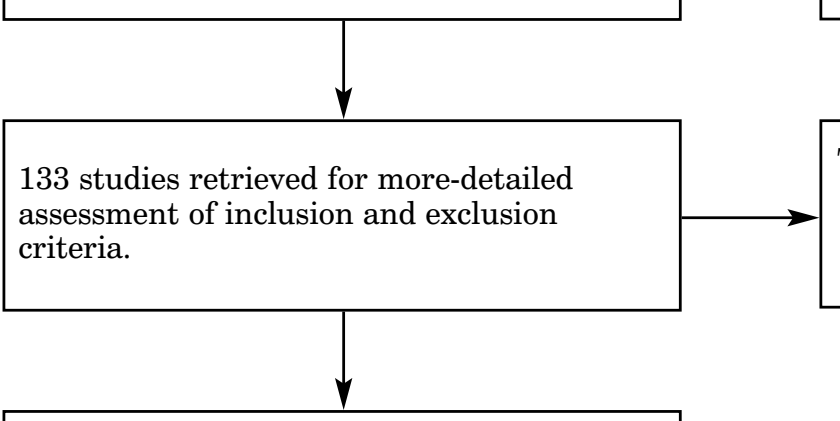

62 studies included in systematic review.

the authors' assessments. Species and strains used were (in decreasing frequency): Sprague-Dawley rats, Wistar rats, cats, Long-Evans rats, dogs, unspecified albino rats, Fischer rats, mice, rabbits, sheep, and monkeys.

A wide range of anaesthetic agents were used. Table 1 lists types of anaesthesia and doses, where reported. Pentobarbital was commonly used at doses from $20 \mathrm{mg} / \mathrm{kg}$ to $70 \mathrm{mg} / \mathrm{kg}$.

\section{Description of assessments performed}

A wide variety of scales were used to measure functional outcome, and more than one scale was used in many studies. The BBB locomotor rating scale, the Rivlin and Tator inclined plane test, and the Tarlov or modified Tarlov motor scale were used in 18, 22 and 10 studies, respectively. Functional scales that were unspecified, or were created by the authors, were used in 17 studies. Other functional evaluations included bladder function, thoracolumbar height measurement, and swimming. The follow-up duration ranged from 24 hours to 25 weeks.

\section{The method of MP administration}

The dose, timing and duration of MP administration varied widely. Initial MP doses were given at a range of time-points, from "immediately" to up to 48 hours post-injury. The doses of MP administered ranged from $8 \mathrm{mg}-300 \mathrm{mg} / \mathrm{kg}$. The duration of treatment with MP ranged from a single dose to continuous infusion or repeated doses for up to 25 weeks. The most common regimen was a single $30 \mathrm{mg} / \mathrm{kg}$ dose, administered within one hour of
3160 citations excluded for the following reasons:

3151 not assessing MP in animals for acute SCI;

4 in which MP given as pre-treatment or for

non-traumatic SCI;

5 non-English language.
71 studies excluded for the following reasons: 7 had no MP-only arm directly compared with placebo; 63 had no functional outcome; 1 review of earlier study. injury (25 studies). Only two studies followed the clinical regimen of $30 \mathrm{mg} / \mathrm{kg}$ within eight hours of injury, then $5.4 \mathrm{mg} / \mathrm{kg} / \mathrm{hr}$ for 24 hours $(6,7)$.

\section{Quality of the studies}

Tables 2 and 3 describe the quality of the studies. Blinding was reported for functional measurement in $73 \%$ of the studies, and randomisation of treatment allocation was reported in 53\% (Table 2).

The reporting of physiological parameters monitored was rated as good in $10 \%$, fair in $2 \%$, and poor in $23 \%$ of the studies; $66 \%$ did not report any parameters (Table 3). The most commonly-reported parameter was body temperature. The reporting of housing and handling procedures was rated as good in $2 \%$, fair in $39 \%$, and poor in $32 \%$ of the studies; $27 \%$ did not provide any information on housing and handling. Of the 20 studies for which the numbers of animals housed per cage were reported, animals were housed individually in ten studies and in pairs in eight studies. In one study, some animals were housed individually and some in pairs, and in another study, there were four animals per cage.

\section{Results of interventions}

Twenty-one (34\%) of the studies showed beneficial effects of MP administration, 36 (58\%) showed no effects, and 5 (8\%) revealed mixed results, depending on the dosing regimen of MP and/or the test used to assess functional outcome.

Among the studies showing a statistically-significant benefit of MP administration, the initial timing of administration ranged from "immediately 


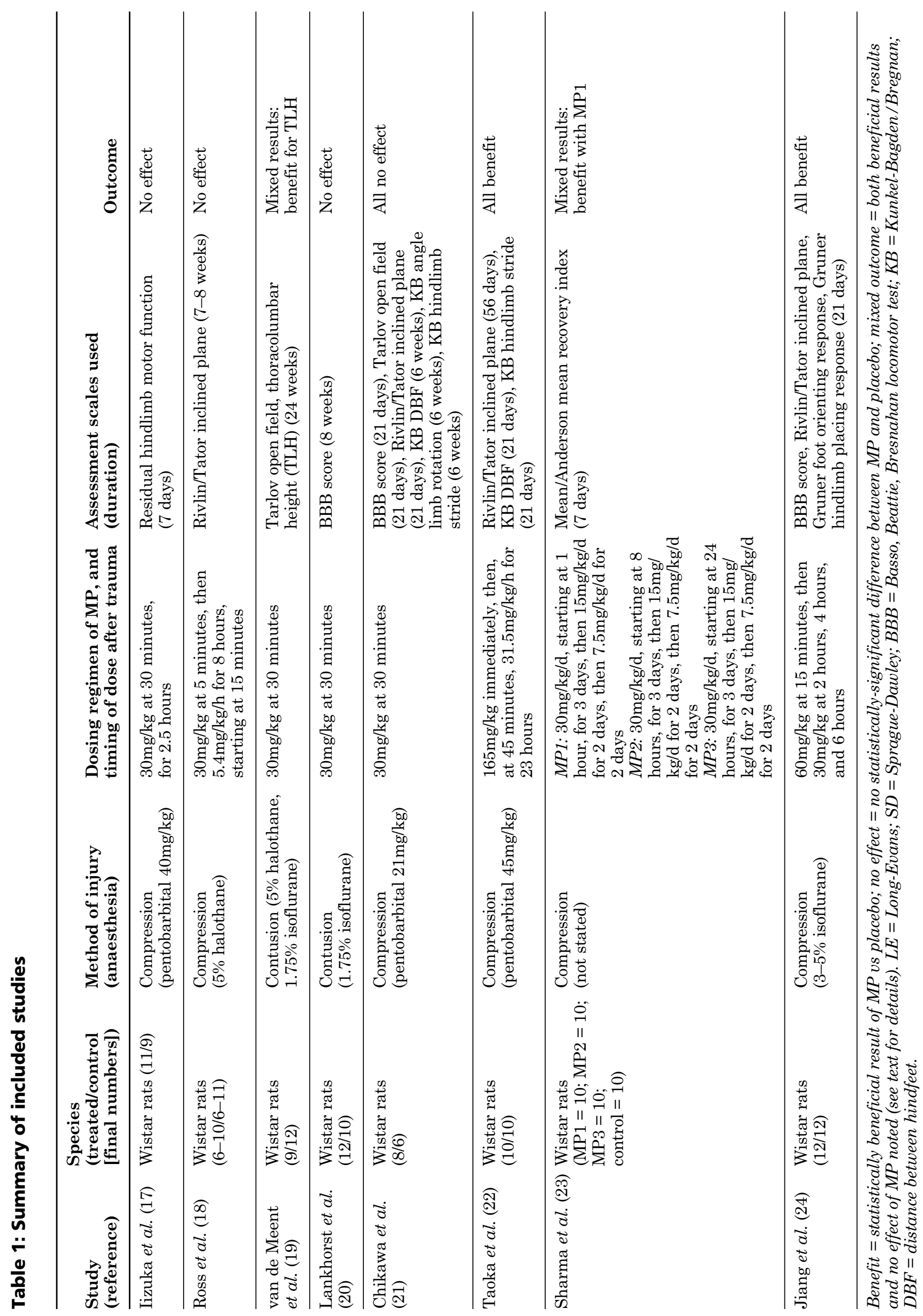




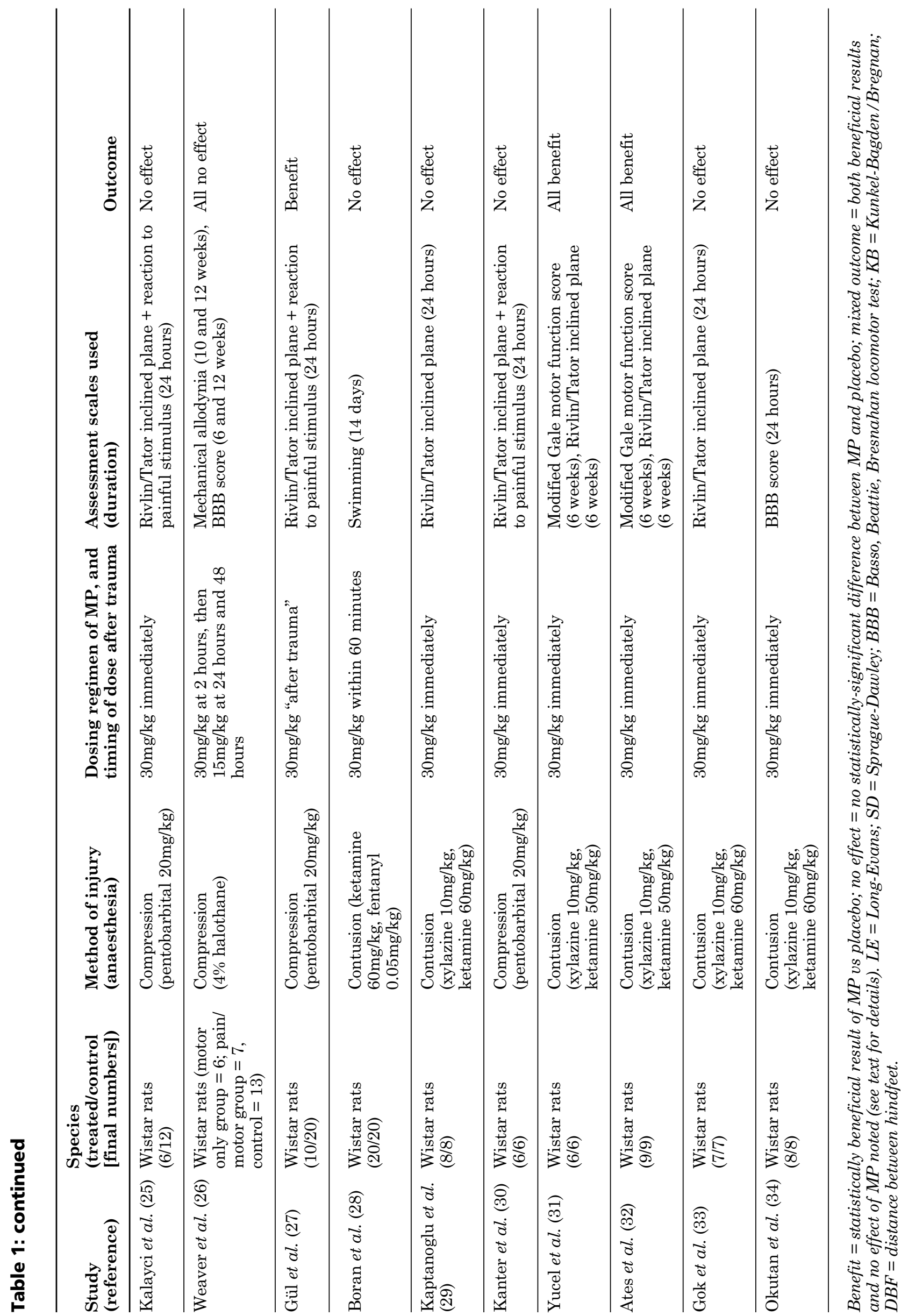




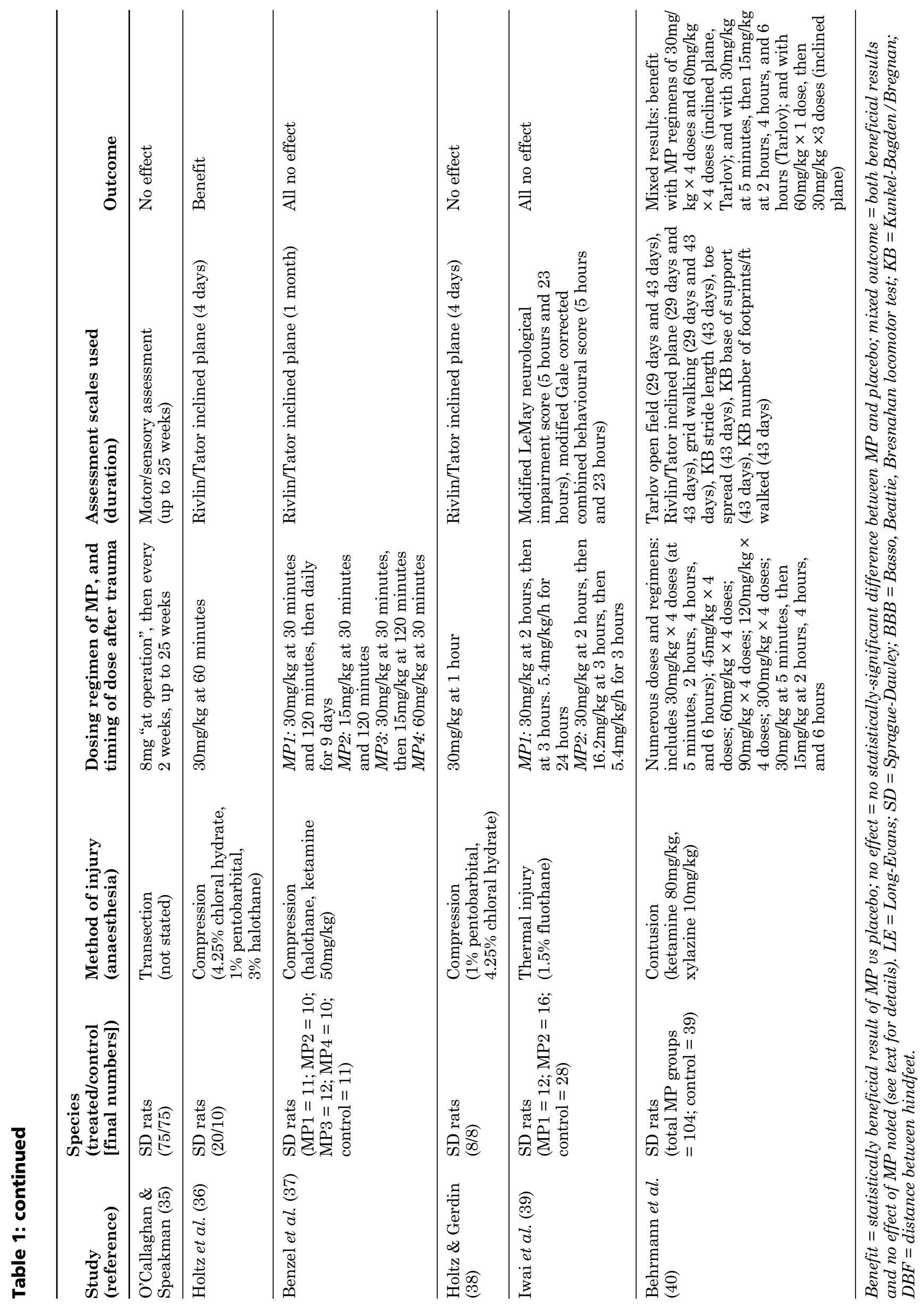




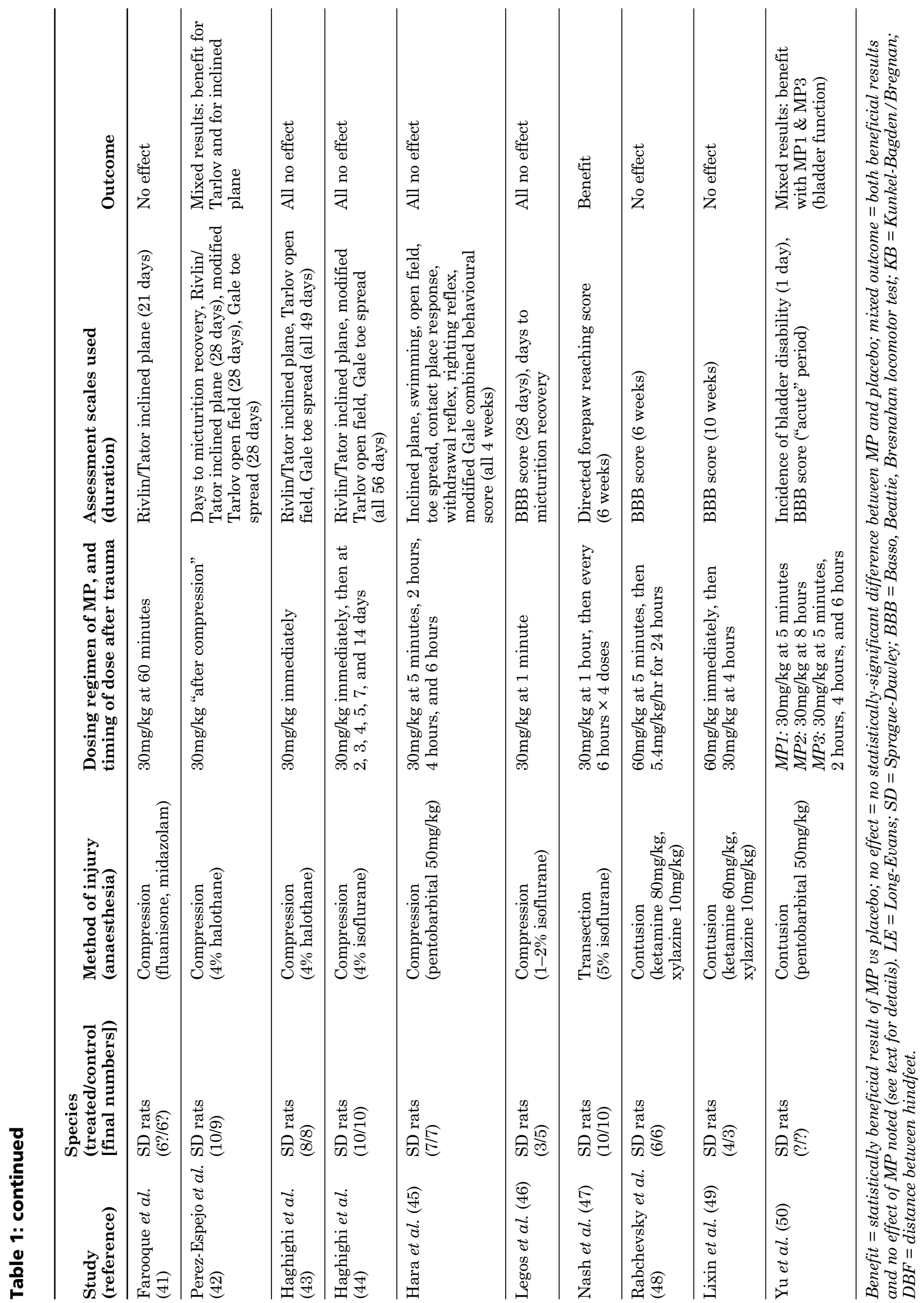




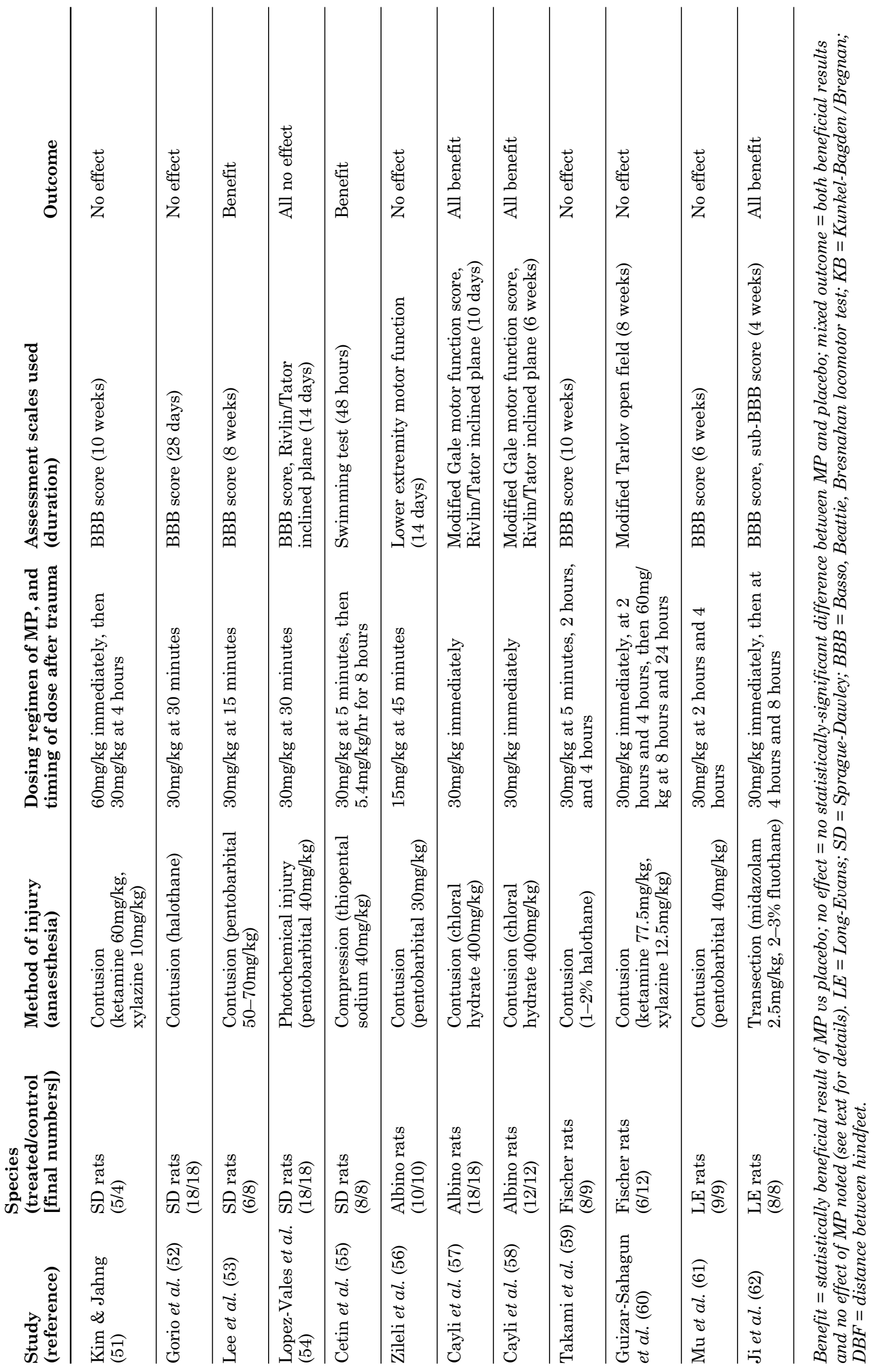




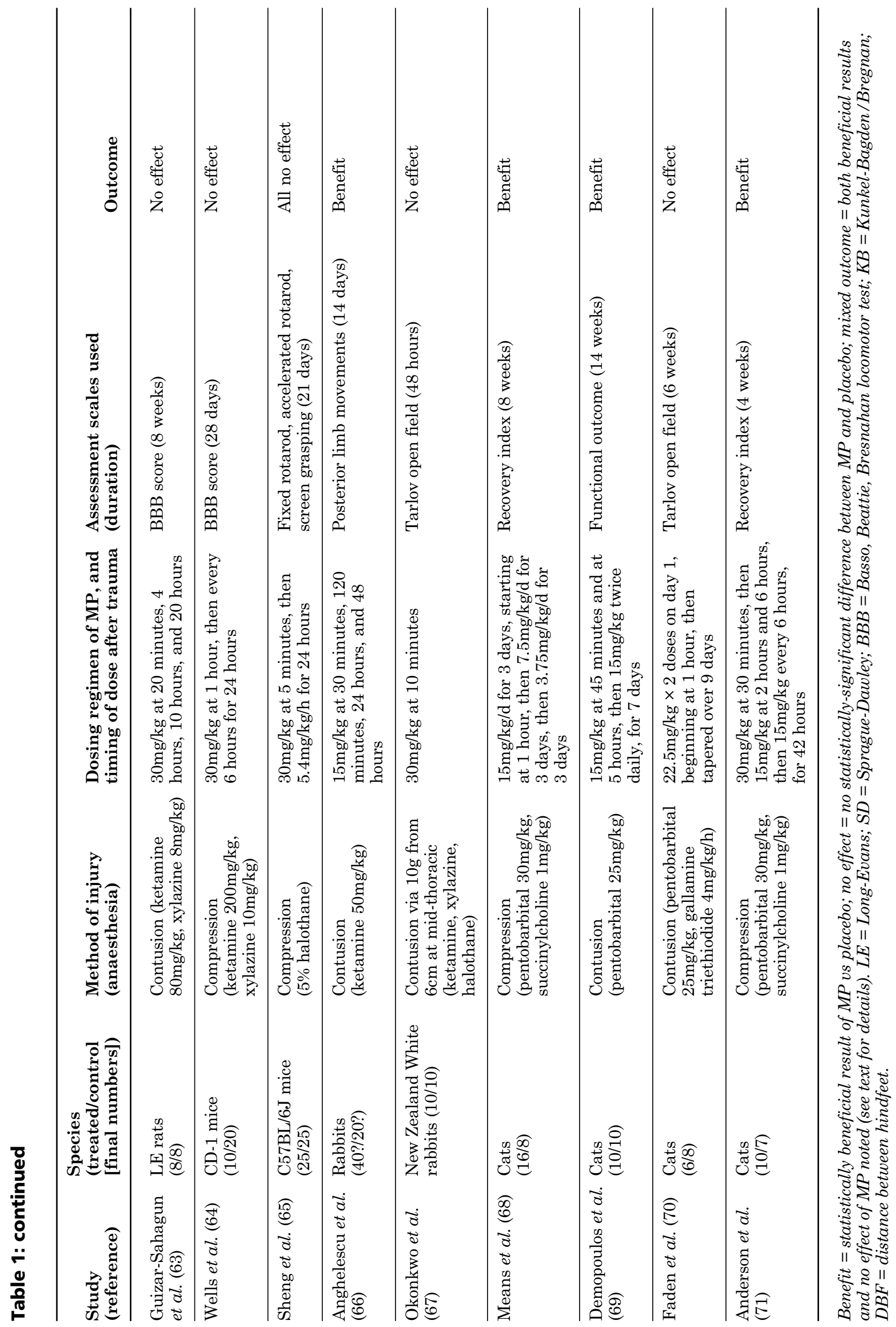




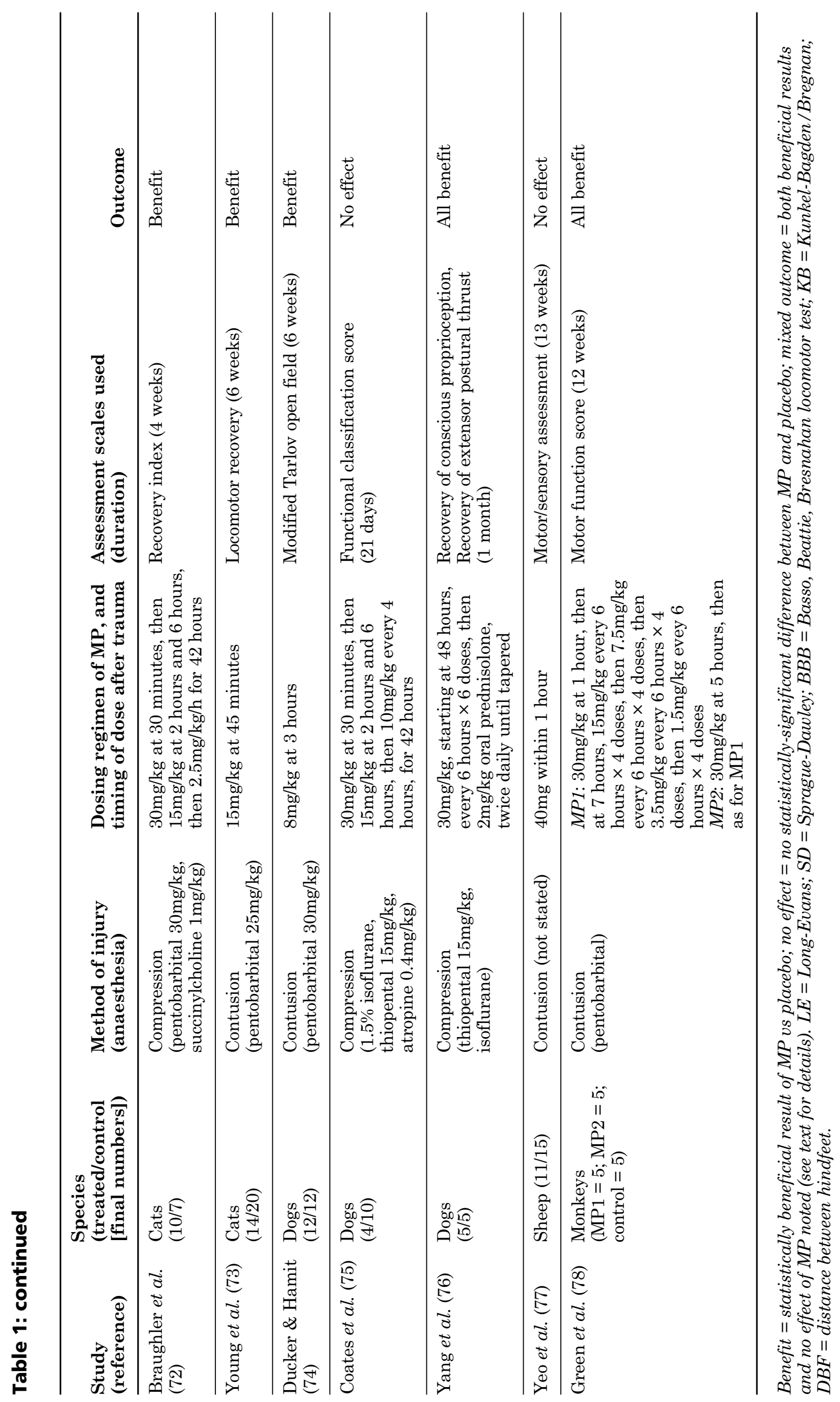


Table 2: The quality of the studies: blinding and randomisation

\begin{tabular}{|c|c|c|}
\hline Study (reference) & B & $\mathbf{R}$ \\
\hline $\begin{array}{l}\text { Iizuka et al. (17) } \\
\text { Ross et al. }(18) \\
\text { van de Meent et al. (19) } \\
\text { Lankhorst et al. (20) } \\
\text { Chikawa et al. }(21)\end{array}$ & $\begin{array}{l}\mathrm{N} \\
\mathrm{Y} \\
\mathrm{Y} \\
\mathrm{Y} \\
\mathrm{Y}\end{array}$ & $\begin{array}{l}\mathrm{N} \\
\mathrm{N} \\
\mathrm{Y} \\
\mathrm{Y} \\
\mathrm{N}\end{array}$ \\
\hline $\begin{array}{l}\text { Taoka et al. }(22) \\
\text { Sharma et al. }(23) \\
\text { Jiang et al. }(24) \\
\text { Kalayci et al. }(25) \\
\text { Weaver et al. }(26)\end{array}$ & $\begin{array}{l}\mathrm{Y} \\
\mathrm{N} \\
\mathrm{Y} \\
\mathrm{N} \\
\mathrm{Y}\end{array}$ & $\begin{array}{l}\mathrm{N} \\
\mathrm{N} \\
\mathrm{Y} \\
\mathrm{N} \\
\mathrm{N}\end{array}$ \\
\hline $\begin{array}{l}\text { Gül et al. (27) } \\
\text { Boran } \text { et al. }(28) \\
\text { Kaptanoglu et al. (29) } \\
\text { Kanter et al. (30) } \\
\text { Yucel et al. (31) }\end{array}$ & $\begin{array}{l}\mathrm{N} \\
\mathrm{Y} \\
\mathrm{Y} \\
\mathrm{N} \\
\mathrm{Y}\end{array}$ & $\begin{array}{l}\mathrm{N} \\
\mathrm{Y} \\
\mathrm{Y} \\
\mathrm{N} \\
\mathrm{Y}\end{array}$ \\
\hline $\begin{array}{l}\text { Ates et al. (32) } \\
\text { Gok et al. }(33) \\
\text { Okutan et al. (34) } \\
\text { O'Callaghan \& Speakman (35) } \\
\text { Holtz et al. (36) }\end{array}$ & $\begin{array}{l}\mathrm{Y} \\
\mathrm{Y} \\
\mathrm{Y} \\
\mathrm{N} \\
\mathrm{N}\end{array}$ & $\begin{array}{l}\mathrm{Y} \\
\mathrm{Y} \\
\mathrm{Y} \\
\mathrm{N} \\
\mathrm{N}\end{array}$ \\
\hline $\begin{array}{l}\text { Benzel et al. }(37) \\
\text { Holtz \& Gerdin (38) } \\
\text { Iwai et al. (39) } \\
\text { Behrmann } \text { et al. (40) } \\
\text { Farooque et al. (41) }\end{array}$ & $\begin{array}{l}\mathrm{Y} \\
\mathrm{N} \\
\mathrm{Y} \\
\mathrm{Y} \\
\mathrm{N}\end{array}$ & $\begin{array}{l}\mathrm{Y} \\
\mathrm{N} \\
\mathrm{N} \\
\mathrm{Y} \\
\mathrm{N}\end{array}$ \\
\hline $\begin{array}{l}\text { Perez-Espejo et al. (42) } \\
\text { Haghighi et al. }(43) \\
\text { Haghighi et al. }(44) \\
\text { Hara et al. }(45) \\
\text { Legos et al. }(46)\end{array}$ & $\begin{array}{l}\mathrm{Y} \\
\mathrm{Y} \\
\mathrm{Y} \\
\mathrm{Y} \\
\mathrm{Y}\end{array}$ & $\begin{array}{l}\mathrm{Y} \\
\mathrm{Y} \\
\mathrm{Y} \\
\mathrm{Y} \\
\mathrm{Y}\end{array}$ \\
\hline $\begin{array}{l}\text { Nash et al. (47) } \\
\text { Rabchevsky et al. (48) } \\
\text { Lixin et al. (49) } \\
\text { Yu et al. }(50) \\
\text { Kim \& Jahng (51) }\end{array}$ & $\begin{array}{l}\mathrm{Y} \\
\mathrm{Y} \\
\mathrm{Y} \\
\mathrm{Y} \\
\mathrm{Y}\end{array}$ & $\begin{array}{l}\mathrm{Y} \\
\mathrm{Y} \\
\mathrm{Y} \\
\mathrm{N} \\
\mathrm{N}\end{array}$ \\
\hline
\end{tabular}

$B=$ reporting of blinding; $R=$ reporting of randomisation .

after" injury up to 48 hours post-injury, with doses ranging from $8-165 \mathrm{mg} / \mathrm{kg}$ (Table 1). Among the studies showing no effects, the initial timing of MP administration ranged from "immediately after" injury up to 24 hours post-injury, with doses ranging from $8 \mathrm{mg}-300 \mathrm{mg} / \mathrm{kg}$.

Benefits were obtained both with a single dose of MP, administered within five minutes of injury, and with repeated doses administered for up to nine days. Results showing no effects were also obtained both with a single dose of MP, administered within five minutes, and with repeated doses administered for up to 25 weeks.

\begin{tabular}{|c|c|c|}
\hline Study (reference) & B & $\mathbf{R}$ \\
\hline $\begin{array}{l}\text { Gorio et al. }(52) \\
\text { Lee et al. }(53) \\
\text { Lopez-Vales et al. (54) } \\
\text { Cetin et al. }(55) \\
\text { Zileli et al. }(56)\end{array}$ & $\begin{array}{l}\mathrm{Y} \\
\mathrm{N} \\
\mathrm{Y} \\
\mathrm{N} \\
\mathrm{N}\end{array}$ & $\begin{array}{l}\mathrm{N} \\
\mathrm{Y} \\
\mathrm{N} \\
\mathrm{Y} \\
\mathrm{N}\end{array}$ \\
\hline $\begin{array}{l}\text { Cayli et al. }(57) \\
\text { Cayli et al. }(58) \\
\text { Takami et al. }(59) \\
\text { Guizar-Sahagun et al. (60) } \\
\text { Mu et al. }(61)\end{array}$ & $\begin{array}{l}\mathrm{N} \\
\mathrm{Y} \\
\mathrm{Y} \\
\mathrm{Y} \\
\mathrm{Y}\end{array}$ & $\begin{array}{l}\mathrm{Y} \\
\mathrm{Y} \\
\mathrm{N} \\
\mathrm{Y} \\
\mathrm{Y}\end{array}$ \\
\hline $\begin{array}{l}\text { Ji et al. (62) } \\
\text { Guizar-Sahagun et al. (63) } \\
\text { Wells et al. (64) } \\
\text { Sheng et al. (65) } \\
\text { Anghelescu et al. (66) }\end{array}$ & $\begin{array}{l}\mathrm{Y} \\
\mathrm{Y} \\
\mathrm{N} \\
\mathrm{Y} \\
\mathrm{N}\end{array}$ & $\begin{array}{l}\mathrm{N} \\
\mathrm{Y} \\
\mathrm{N} \\
\mathrm{Y} \\
\mathrm{N}\end{array}$ \\
\hline $\begin{array}{l}\text { Okonkwo et al. (67) } \\
\text { Means et al. }(68) \\
\text { Demopoulos et al. (69) } \\
\text { Faden et al. }(70) \\
\text { Anderson et al. }(71)\end{array}$ & $\begin{array}{l}\mathrm{Y} \\
\mathrm{Y} \\
\mathrm{Y} \\
\mathrm{Y} \\
\mathrm{N}\end{array}$ & $\begin{array}{l}\mathrm{Y} \\
\mathrm{N} \\
\mathrm{N} \\
\mathrm{N} \\
\mathrm{N}\end{array}$ \\
\hline $\begin{array}{l}\text { Braughler et al. }(72) \\
\text { Young et al. }(73) \\
\text { Ducker \& Hamit }(74) \\
\text { Coates et al. }(75) \\
\text { Yang et al. }(76)\end{array}$ & $\begin{array}{l}\mathrm{Y} \\
\mathrm{Y} \\
\mathrm{Y} \\
\mathrm{Y} \\
\mathrm{N}\end{array}$ & $\begin{array}{l}\mathrm{Y} \\
\mathrm{Y} \\
\mathrm{Y} \\
\mathrm{N} \\
\mathrm{Y}\end{array}$ \\
\hline $\begin{array}{l}\text { Yeo et al. }(77) \\
\text { Green } \text { et al. }(78)\end{array}$ & $\begin{array}{l}\mathrm{Y} \\
\mathrm{Y}\end{array}$ & $\begin{array}{l}\mathrm{N} \\
\mathrm{Y}\end{array}$ \\
\hline $\begin{array}{l}\text { Total number reporting } \\
(\%)\end{array}$ & $\begin{array}{c}45 \\
(73)\end{array}$ & $\begin{array}{c}33 \\
(53)\end{array}$ \\
\hline
\end{tabular}

Table 4 classifies the results of the studies by species and strain. Overall, there were more studies showing benefits of MP treatment in cats (five of six studies) and dogs (two of three studies). Both of the mouse studies which were assessed showed no effects of MP administration. The results in rats varied between and within strains, although there were, overall, more studies showing no effects (30 of 47 studies) than beneficial effects. Five studies in rats showed mixed results. One rabbit study found beneficial effects of MP treatment, and the other found no effects. The single study on monkeys showed that MP treatment was beneficial, 
and the single study on sheep found no effects. Table 5 classifies the results of the studies by injury method. The results varied within and between the different injury methods.

In an effort to detect any patterns in the results, we further narrowed the criteria of the analysed studies. We looked at the studies in which MP was administered as a single $30 \mathrm{mg} / \mathrm{kg}$ dose, within one hour of injury. With this common MP dosing regimen, seven out of these 25 studies (28\%) found beneficial effects, 15 (60\%) showed no effects, and three $(12 \%)$ showed mixed results.

Among these 25 common MP dosing regimen studies, one of the eight which assessed BBB scores (13\%) found beneficial effects, and seven of these eight (88\%) showed no effects. Seven of the 16 which performed Rivlin and Tator inclined plane tests (44\%) found beneficial effects, and nine of these 16 (56\%) found no effects. One of the five which used the Tarlov or modified Tarlov open-

Table 3: The quality of the studies: Reporting of housing and handling procedures, and monitoring of physiological parameters

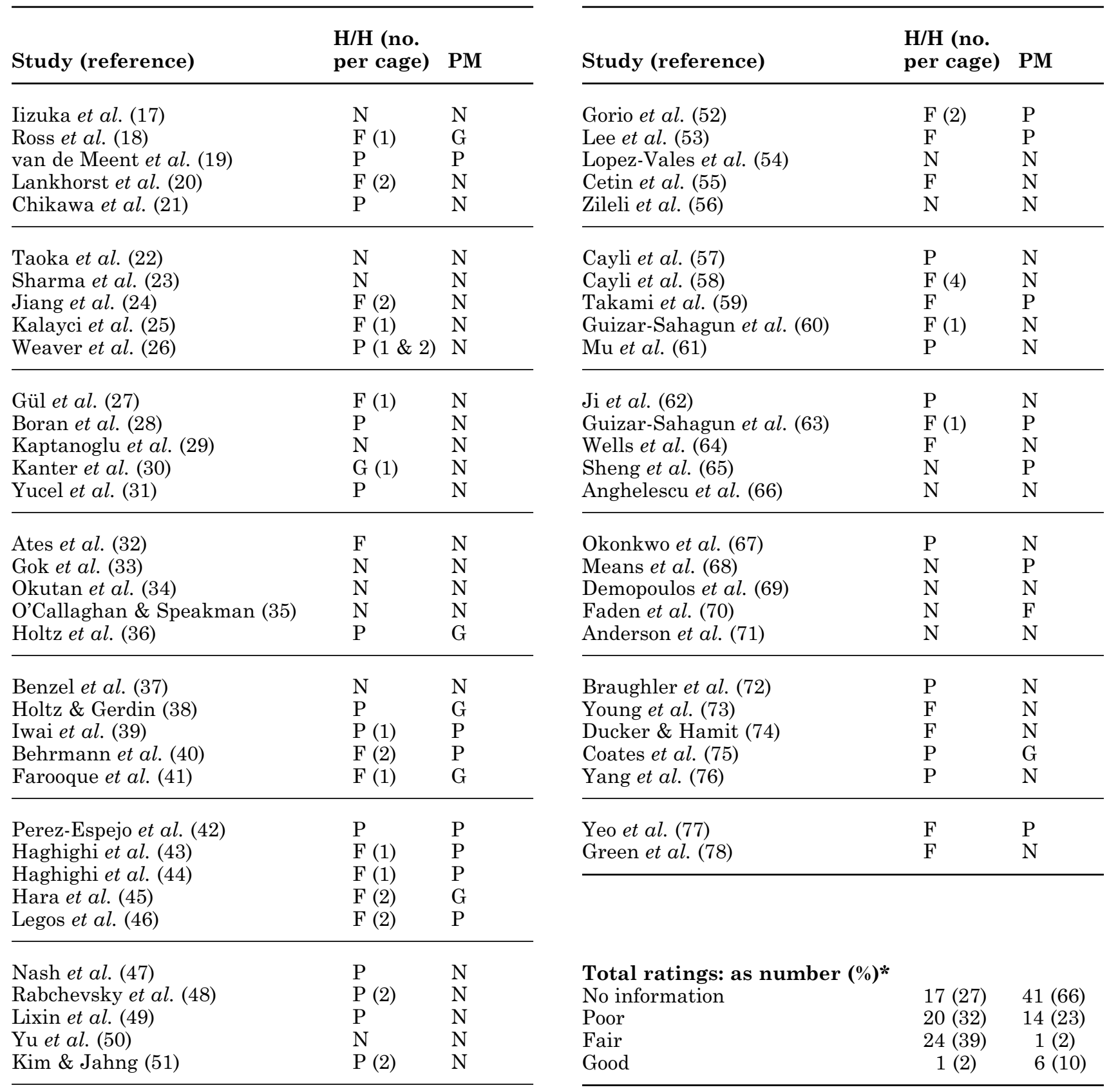

$H / H=$ reporting of housing and handling procedures; $P M=$ monitoring of physiological parameters; $P=$ poor; $F=$ fair $; G=\operatorname{good}($ see text for definitions); $N=$ no information. *Total may not equal $100 \%$ due to rounding. 
Table 4: Results of the studies by species/strain

\begin{tabular}{lcccc}
\hline Species/ & $\begin{array}{c}\text { No. of } \\
\text { studies }\end{array}$ & $\begin{array}{c}\text { Benefit } \\
\text { n (\%) }\end{array}$ & $\begin{array}{c}\text { No } \\
\text { effect } \\
\text { n (\%) }\end{array}$ & $\begin{array}{c}\text { Mixed } \\
\text { results } \\
\mathbf{n}(\%)\end{array}$ \\
\hline Wistar rat & 18 & $5(28)$ & $11(61)$ & $2(11)$ \\
SD rat & 21 & $4(19)$ & $14(67)$ & $3(14)$ \\
Albino rat & 3 & $2(67)$ & $1(33)$ & $0(0)$ \\
Fischer rat & 2 & $0(0)$ & $2(100)$ & $0(0)$ \\
LE rat & 3 & $1(33)$ & $2(67)$ & $0(0)$ \\
\hline Mouse & 2 & $0(0)$ & $2(100)$ & $0(0)$ \\
Rabbit & 2 & $1(50)$ & $1(50)$ & $0(0)$ \\
Cat & 6 & $5(83)$ & $1(17)$ & $0(0)$ \\
Dog & 3 & $2(67)$ & $1(33)$ & $0(0)$ \\
Sheep & 1 & $0(0)$ & $1(100)$ & $0(0)$ \\
Monkey & 1 & $1(100)$ & $0(0)$ & $0(0)$ \\
\hline
\end{tabular}

$S D=$ Sprague-Dawley $;$ LE = Long-Evans.

field tests (20\%) found beneficial effects, and four of these five (80\%) found no effects.

The results also varied among those studies giving a single dose of $30 \mathrm{mg} / \mathrm{kg}$ MP "immediately after" injury, or within five minutes. Five of these $14(36 \%)$ studies found beneficial effects, seven (50\%) showed no effects, and two (14\%) showed mixed results. Among the 39 studies assessing functional outcome for at least 28 days, 15 (38\%) found beneficial effects, 21 (54\%) showed no effects, and three (8\%) showed mixed results. Among the 22 studies reporting both randomisation and blinding, and with durations of at least 28 days, eight (36\%) found beneficial effects, 11 (50\%) showed no effects, and three (14\%) showed mixed results. The two studies following the current standard clinical dose and regimen of MP $(6,7)$ showed no effects.

\section{Discussion}

\section{Variability in the results}

The most conspicuous pattern to emerge from our analysis is the pronounced variability in the animal study results, and thus the inability of these results to predict human clinical outcomes. In rodents (a total of 47 studies), more studies showed no effect than showed overall benefit, but studies on cats (six studies), dogs (three studies) and monkeys (one study) revealed more benefit than nonbenefit from MP treatment.

Results showing both benefit and non-benefit were found with the same initial dose and timing of MP administration, with the same functional assessment scale, and with the same duration of follow-up. However, our study was not a metaanalysis. Disparate intervention regimens, durations, and outcome assessments, and the absence of detailed statistical reporting in many studies, preclude the pooling of results.

\section{Variability in study design and implementation}

What factors might lead to such variability in results? Inter-laboratory and intra-laboratory differences in study design and quality could be involved. Only slightly greater than half of the studies reported randomisation of intervention, which, even if implemented, may not have the standardisation benefits intended in human studies. Many studies lacked any blinding of functional evaluation, which can also affect outcomes. Very few studies reported physiological parameters, such as blood pressure, heart rate and blood gases, during injury induction. These parameters may play a role in spinal cord lesion volume (79).

The anaesthesia used during injury induction varied widely in both type and dose. Anaesthetic agents may affect the response to SCI by altering physiological parameters and having intrinsic neuroprotective effects (79). In Sprague-Dawley rats, for example, sevoflurane provided protection against cerebral ischaemia (80), and bupivacaine protected against extended spinal cord lesions after injury (81). The studies also varied with respect to the functional scale used and the duration of follow-up. Variability in any one of these parameters could cause differences in outcomes.

Differences in housing and handling procedures can also affect study outcomes. Animal housing conditions, and handling by personnel, can affect metabolic parameters such as cortisone secretion, cholesterol level, heart rate and blood pressure, all of which may induce neurological and other changes and thus alter physical function (14, 82-84). Enriched housing stimulates neurogenesis, changes in synaptic signalling, and altered gene expression, across a variety of species and strains (14).

\section{Table 5: Results of the studies by injury}

\begin{tabular}{lcccc}
\hline $\begin{array}{l}\text { Injury } \\
\text { method }\end{array}$ & $\begin{array}{c}\text { No. of } \\
\text { studies }\end{array}$ & $\begin{array}{c}\text { Benefit } \\
\mathbf{n}(\%)\end{array}$ & $\begin{array}{c}\text { No } \\
\text { effect } \\
\mathbf{n}(\%)\end{array}$ & $\begin{array}{c}\text { Mixed } \\
\text { results } \\
\mathbf{n}(\%)\end{array}$ \\
\hline Compression* & 27 & $9(33)$ & $16(59)$ & $2(7)$ \\
Contusion & 30 & $10(33)$ & $17(57)$ & $3(10)$ \\
Transection* & 3 & $2(67)$ & $1(33)$ & $0(0)$ \\
Other & 2 & $0(0)$ & $2(100)$ & $0(0)$ \\
\hline
\end{tabular}

*Total not equal to $100 \%$ due to rounding. 
Routine procedures and environmental conditions, such as cage size, cage movement, handling, and type of cage ventilation, lead to significant, lasting changes in physiological parameters and behaviour $(83,85,86)$. Animals caged in groups and/or enriched environments tend to score differently in functional assessments than animals housed individually and in standard cages (82). Enriched housing improves function in animals after SCI or other central nervous system lesions (87-89), and can induce significant changes in physiology, behaviour, and anatomical development (85). Changes in physiological parameters as a result of housing and handling procedures, can also be species-specific or strain-specific (90). As demonstrated by this review, the reporting of these procedures is grossly deficient, which hampers any cross-study comparisons.

Animal research is intended, in part, to inform research into human conditions and their interventions, particularly when the animal research aims to address potential human responses to treatments. The variability in animal research results renders the prediction of human outcomes problematic. Due to pronounced inter-laboratory and intra-laboratory variations in injury method, species, anaesthesia, duration, functional outcome tests, and housing and handling procedures, there have been calls for standardisation in SCI research protocols (91-93).

This is probably not an attainable goal. For example, the designers of the New York University (NYU) impactor model mandated certain conditions in experimental procedures in an attempt to standardise SCI. Yet, as Kwon et al. (94) state, "in practice... it would appear that not all these stringent conditions (e.g. anaesthetic doses, rat strain) are adhered to by every centre that possesses an NYU impactor". In addition to the injury procedures, there might simply be too many variables to achieve putative standardisation. Many of these variables are intrinsic to the studies themselves, and thus are unavoidable. In addition, animals might still react differently to the same controlled conditions. In terms of mouse behaviour, at least, standardisation has proved elusive $(95,96)$.

\section{Inter-species and inter-strain differences}

Even if the standardisation of all study design variables and procedures could be accomplished, would there still be translational difficulties for pharmacological studies in SCI? While we were not able to control for all the factors, we found that, even when many of these factors were controlled for, variability in results remained. This suggests that: a) the uncontrolled factors (such as housing and handling procedures) account for significant variation in results; and/or b) other factors inher- ent to the animal models themselves might account for some of the variability in results.

Differences in spinal cord neuroanatomy, physiology and reaction to injury, both among and within species and strains, could further hamper extrapolation to humans. For example, in response to acute SCI, mice develop a significant connective tissue matrix and minimal central cavities, in comparison to rats (97). Astrocytic response, lesion size, and neurofilament crossing into the lesion site, all differ substantially among hamsters, mice, and rats (98). Dogs, guinea-pigs, and rats have increased collateralisation of spinal cord blood vessels compared to cats and rabbits (99). Both qualitative and quantitative differences in inflammatory response, neurodegeneration, and other pathological features of secondary injury and wound healing mechanisms, vary among different strains of mice and rats (100-102).

All these inherent and immutable physiological differences make translation of acute SCI animal research results to humans problematic. As a practical matter, these differences also suggest that much more than animal model selection, study design and performance criteria, stand between these animal results and human applications (103).

\section{Limitations of systematic reviews}

Systematic reviews are vulnerable to various forms of bias. Our search was limited to published studies referenced in an electronic database; there may also be relevant unpublished studies. If such a publication bias against negative animal studies exists, then it is possible that our review would demonstrate more studies showing no effect, if unpublished studies were included. In addition, the quality of this review is inherently influenced by the quality of each individual study. Possible bias in individual studies, due to lack of randomisation or blinding of assessment outcome, will be reflected in this review. We tried to minimise these biases by performing a subgroup analysis of only those studies which reported both randomisation and blinding.

\section{Alternative approaches to the understanding of human SCI}

Currently, most of the pre-clinical work in SCI involves animal models. The barriers to successful translation of animal SCI studies to human clinical relevance underscore the need to develop and use more validated human-based testing methods. It is troubling that there is a dearth of research to further the understanding of the pathology of human spinal cord injury in comparison to that in other animals (104). The use of human cadavers, 
imaging techniques and electrodiagnostic studies, to unravel the pathophysiological changes after human spinal cord injury, need to be given greater priority in SCI research.

Many in vitro and in silico models have been developed, examples of which include: a model of the glial scar that develops after spinal cord injury (105); an in vitro model of axonal injury (106); and an in silico model of axonal injury and repair (107). These models provide the opportunity to define the mechanisms and intracellular signalling pathways associated with SCI and SCI treatment. Many of these in vitro models simulate the various forms of SCI. One model system involves the use of a laser to simulate transection injury $(108,109)$. By using this model, a defined physiological process in a single cell can be determined at a precise distance from the cell body and transected. Other in vitro models include the simulation of contusion injury by the dropping of weights onto cultured spinal tissue (110), and the deformation of cultured neural cells by the manipulation of an adherent silicone plate, to simulate stretch injury (111). These and other in vitro models have been particularly instrumental in increasing understanding of genetic, biochemical and pathological responses to spinal cord injury and for the testing of neuroprotective agents. For example: a transection laser model revealed the depolarisation of neuronal cell bodies after injury, and also the factors that affected this depolarisation (108); in a study of dendrites that were transected from spinal cells via laser cell surgery, researchers noted a relation between neuronal death and increases in jun gene expression (109); and research with an in vitro mechanical injury model showed that lazaroids and other inhibitors of lipid peroxidation inhibited cell death (112).

Many of these techniques involve the use of animal, rather than human, neural cells and tissues. Thus, inter-species barriers to extrapolation are likely to be factors which limit their effectiveness. In contrast, in 2000, researchers developed a technique to immortalise human motoneurons and, in 1999, immortalised human cells that differentiate into sensory neurons with nociceptive properties were produced $(113,114)$. Researchers at the University of Miami are collaborating on the Human Spinal Cord Injury Model Project, which correlates a patient's neurological function with neurophysiological status, imaging studies and histopathology (115).

While they show great promise as tools to understand human SCI and to test novel neuroprotective agents, these models are still in their early stages of development and validation. Thus, their effectiveness cannot be evaluated at this time. However, potential limitations to some or all of the above methods include: a) a lack of correlation between the cellular model and human in vivo neurophysiology; b) unpredictable transformation of cell lines, to allow in vitro growth; c) a lack of active metabolites or metabolic activation, required for some of the investigational drugs; and d) an insufficient modelling of the spinal microenvironment in in vitro models, particularly with respect to vasculature. The use of a combination of human-specific models, such as various in vitro models, imaging studies, histopathology studies, and in silico models, may provide the most complete understanding of human SCI.

\section{Conclusion}

This review demonstrates the barriers to the prediction of the effectiveness of MP treatment in human SCI based on animal studies. The effectiveness of MP treatment differed, both among and within species. There are several possible explanations for these differences, which include variability in study design and poor methodological quality. However, the complete elimination of these variables is unlikely, and even if it were achieved, it would not fully address the demonstrated inconsistency of results within subgroups with similar study design and improved methodology. This suggests that other immutable factors, such as inter-species and inter-strain differences in neurophysiology and in responses to injury and treatment, account for some of the discrepancies.

Preclinical studies are used to inform clinical trials. It is unlikely that the animal experimental data will be further used to inform clinical use of MP. However, the animal studies of novel neuroprotective agents still involved in pre-clinical testing, will be used to inform clinical trials. This analysis of MP, used as a test case, illustrates the numerous barriers to reliably using the animal studies to inform human intervention in SCI. The results of these animal tests may theoretically be more reliable, if the testing is focused only on relevant and validated model(s), where known human parameters were included in the validation process. However, there is no such model, nor is it likely that any such a model could be developed, due to interspecies and intra-species differences. Therefore, research emphasis should be on the development and use of validated human-based methods.

\section{Acknowledgements}

We are grateful to the following for commenting on the manuscript, and providing helpful suggestions: Dr Edward Seljeskog, Dr Jonathan P. Balcombe, Dr Marius Maxwell, and Dr Lawrence A. Hansen.

Received 27.03.08; received in final form 15.08.08; accepted for publication 08.09.08. 


\section{References}

1. Faden, I. \& Stoica, B. (2007). Neuroprotection. Challenges and opportunities. Archives of Neurology 64, 794-800.

2. Benatar, M. (2007). Lost in translation: Treatment trials in the SOD1 mouse and in human ALS. Neurobiology of Disease 26, 1-13.

3. Pound, P., Ebrahim, S., Sandercock, P., Bracken, M.B. \& Roberts, I. (2004). Where is the evidence that animal research benefits humans? British Medical Journal 328, 514-517.

4. Perel, P., Roberts, I., Sena, E., Wheble, P., Briscoe, C., Sandercock, P., Macleod, M., Mignini, L.E., Jayaram, P. \& Khan, K.S. (2007). Comparison of treatment effects between animal experiments and clinical trials: systematic review. British Medical Journal 334, 197.

5. Gawrylewski, A. (2007). The trouble with animal models. Why did human trials fail? The Scientist 21, 44.

6. Bracken, M.B., Shepard, M.J., Holford, T.R., LeoSummers, L., Aldrich, E.F., Fazl, M., Fehlings, M., Herr, D.L., Hitchon, P.W., Marshall, L.F., Nockels, R.P., Pascale, V., Perot, P.L., Piepmeier, J., Sonntag, V.K.H., Wagner, F., Wilberger, J.E., Winn, H.R. \& Young, W. (1997). Administration of methlyprednisolone for 24 or 48 hours or tirilazad mesylate for 48 hours in the treatment of acute spinal cord injury. Results of the Third National Acute Spinal Cord Injury Randomized Controlled Trial. JAMA 277, 1597-1604.

7. Bracken, M.B., Shepard, M.J., Collins, W.F., Holford, T.R., Young, W., Baskin, D.S., Eisenberg, H.M., Flamm, E., Leo-Summers, L. \& Maroon, J. (1990). A randomized, controlled trial of methylprednisolone or naloxone in the treatment of acute spinal-cord injury. Results of the Second National Acute Spinal Cord Injury Study. The New England Journal of Medicine 322, 1405-1411.

8. Bledsoe, B.E., Wesley, A.K. \& Salomone, J.P. (2004). High-dose steroids for acute spinal cord injury in emergency medical services. Prehospital Emergency Care 8, 313-316.

9. Cass, D.E., Dvorak, M.F., Fewer, D.H., Fox, R.J., Hugenholtz, H., Izukawa, D.M.S., Lexchin, J. \& Tuli, S. (2003). Steroids in acute spinal cord injury. Canadian Journal of Emergency Medicine 5, 7-9. Available at: http://caep.ca/CMS/get_file. asp?id=531534FDA9BE41F5BF97BFFA0D1CD96 9\&ext=.pdf\&name=pg7.pdf (Accessed 13.10.08).

10. Hugenholtz, H. (2003). Methylprednisolone for acute spinal cord injury: not a standard of care. Canadian Medical Association Journal 168, 11451146.

11. Bracken, M.B. (2001). Methylprednisolone and acute spinal cord injury. An update of the randomized evidence. Spine 26, S47-S54.

12. Wallman, P. \& Mackway-Jones, K. (2000). Towards evidence based medicine: best BETs from the Manchester Royal Infirmary. Corticosteroids in acute spinal cord injury. Journal of Accident \& Emergency Medicine 17, 215.

13. Coleman, W.P., Benzel, E., Cahill, D.W., Ducker, T., Geisler, F., Green, B., Gropper, M.R., Goffin, J., Madsen III, P.W., Maiman, D.J., Ondra, S.L., Rosner, M., Sasso, R.C., Trost, G.R. \& Zeidman, S. (2000). A critical appraisal of the reporting of the National Acute Spinal Cord Injury Studies (II and
III) of methylprednisolone in acute spinal cord injury. Journal of Spinal Disorders 13, 185-199.

14. Bayne, K. (2005). Potential for unintended consequences of environmental enrichment for laboratory animals and research results. Institute of Laboratory Animal Resources Journal 46, 129139.

15. Horn, J., de Haan, R.J., Vermeulen, M., Luiten, P.G.M. \& Limburg, M. (2001). Nimodipine in animal model experiments of focal cerebral ischemia. A systematic review. Stroke 32, 2433-2438.

16. Lee, D.S., Quang, T.N., Lapointe, N., Austin, P.C., Ohlsson, A., Tu, J.V., Stewart, D.J. \& Rouleau, J.L. (2003). Meta-analysis of the effects of endothelin receptor blockade on survival in experimental heart failure. Journal of Cardiac Failure 9, 368-374.

17. Iizuka, H., Iwasaki, Y., Yamamoto, T. \& Kadoya, S. (1986). Morphometric assessment of drug effects in experimental spinal cord injury. Journal of Neurosurgery 65, 92-98.

18. Ross, I.B., Tator, C.H. \& Theriault, E. (1993). Effect of nimodipine or methylprednisolone on recovery from acute experimental spinal cord injury in rats. Surgical Neurology 40, 461-470.

19. van de Meent, H., Hamers, F.P.T., Lankhorst, A.J., Joosten, E.A.J. \& Gispen, W.H. (1997). Beneficial effects of the melanocortin [alpha]-melanocyte-stimulating hormone on clinical and neurophysiological recovery after experimental spinal cord injury. Neurosurgery 40, 122-131.

20. Lankhorst, A.J., ter Laak, M.P., Hammers, F.P.T. \& Gispen, W.H. (2000). Combined treatment with alpha MSH and methylprednisolone fails to improve functional recovery after spinal injury in the rat. Brain Research 859, 334-340.

21. Chikawa, T., Ikata, T., Katoh, S., Hamada, Y., Kogure, K. \& Fukuzawa, K. (2001). Preventive effects of lecithinized superoxide dismutase and methylprednisolone on spinal cord injury in rats: transcriptional regulation of inflammatory and neurotrophic genes. Journal of Neurotrauma 18, 93-103.

22. Taoka, Y., Okajima, K., Uchiba, M. \& Johno, M. (2001). Methylprednisolone reduces spinal cord injury in rats without affecting tumor necrosis factor-alpha production. Journal of Neurotrauma 18, 533-543.

23. Sharma, A., Tiwari, R., Badhe, P. \& Sharma, G. (2004). Comparison of methylprednisolone with dexamethasone in treatment of acute spinal injury in rats. Indian Journal of Experimental Biology 42, 476-480.

24. Jiang, S., Khan, M.I., Middlemiss, P.J., Lu, Y., Werstiuk, E.S., Crocker, C.E., Ciccarelli, R., Caiagli, F. \& Rathbone, M.P. (2004). AIT-082 and methylprednisolone singly, but not in combination, enhance functional and histological improvement after acute spinal cord injury in rats. International Journal of Immunopathology \& Pharmacology 17, 353-366.

25. Kalayci, M., Coskun, O., Cagavi, F., Kanter, M., Armutcu, F., Gül, S. \& Acikgoz, B. (2005). Neuroprotective effects of ebselen on experimental spinal cord injury in rats. Neurochemical Research 30, 403-410.

26. Weaver, L.C., Gris, D., Saville, L.R., Oatway, M.A., Chen, Y., Marsh, D.R., Hamilton, E.F. \& Dekaban, G.A. (2005). Methylprednisolone causes minimal improvement after spinal cord injury in rats, con- 
trasting with benefits of an anti-integrin treatment Journal of Neurotrauma 22, 1375-1387.

27. Gül, S., Celik, S.E., Kalayci, M., Tasyurekli, M., Cokar, N. \& Bilge, T. (2005). Dose-dependent neuroprotective effects of melatonin on experimental spinal cord injury in rats. Surgical Neurology 64, 355-361.

28. Boran, B.O., Colak, A. \& Kutlay, M. (2005). Erythropoietin enhances neurological recovery after experimental spinal cord injury. Restorative Neurology \& Neuroscience 23, 341-345.

29. Kaptanoglu, E., Caner, H., Solaroglu, I. \& Kiline, K. (2005). Mexiletine treatment-induced inhibition of caspase- 3 activation and improvement of behavioral recovery after spinal cord injury. Journal of Neurosurgery. Spine 3, 53-56.

30. Kanter, M., Coskun, O., Kalayci, M., Buyukbas, S. \& Cagavi, F. (2006). Neuroprotective effects of Nigella sativa on experimental spinal cord injury in rats. Human \& Experimental Toxicology 25, 127-133.

31. Yucel, N., Cayli, S.R., Ates, O., Karadag, N., Firat, S. \& Turkoz, Y. (2006). Evaluation of the neuroprotective effects of citoline after experimental spinal cord injury: Improved behavioral and neuroanatomical recovery. Neurochemical Research 31, 767-775.

32. Ates, O., Cayli, S., Altinoz, E., Gurses, I., Yucel, N., Kocak, A., Yologlu, S. \& Turkoz, Y. (2006). Effects of resveratrol and methylprednisolone on biochemical, neurobehavioral and histopathological recovery after experimental spinal cord injury. Acta Pharmacologica Sinica 27, 1317-1325.

33. Gok, B., Okutan, O., Beskonakli, E. \& Kiline, K. (2007). Effects of magnesium sulphate following spinal cord injury in rats. Chinese Journal of Physiology 50, 93-97.

34. Okutan, O., Solaroglu, I., Beskonakli, E. \& Taskin, Y. (2007). Recombinant human erythropoietin decreases myeloperoxidase and caspase-3 activity and improves early functional results after spinal cord injury in rats. Journal of Clinical Neuroscience 14, 364-368.

35. O'Callaghan, W.J. \& Speakman, T.J. (1963). Axon regeneration in the rat spinal cord. Surgical Forum 14, 410-411.

36. Holtz, A., Nystrom, B. \& Gerdin, B. (1990). Effect of methylprednisolone on motor function and spinal cord blood flow after spinal cord compression in rats. Acta Neurological Scandinavica 82, 68-73.

37. Benzel, E.C., Hoffpauir, G.M., Thomas, M.M., Beal, J.A., Lancon, J.A. \& Kesterson, L. (1990). Dose-dependent effects of naloxone and methylprednisolone in the ventral compression model of spinal cord injury. Journal of Spinal Disorders 3, 339-344.

38. Holtz, A. \& Gerdin, B. (1991). Blocking weightinduced spinal cord injury in rats: therapeutic effect of the 21-aminosteroid U74006F. Journal of Neurotrauma 8, 239-245.

39. Iwai, A., Monafo, W.W. \& Eliasson, S.G. (1993). Methylprednisolone treatment of experimental spinal cord injury. Paraplegia 31, 417-429.

40. Behrmann, D.L., Bresnahan, J.C. \& Beattie, M.S (1994). Modeling of acute spinal cord injury in the rat: neuroprotection and enhanced recovery with methylprednisolone, U-74006F and YM-14673. Experimental Neurology 126, 61-75.
41. Farooque, M., Olsson, Y. \& Holtz, A. (1994). Effect of the 21-aminosteroid U74006F and methylprednisolone on motor function recovery and oedema after spinal cord compression in rats. Acta Neurologica Scandinavica 89, 36-41.

42. Perez-Espejo, M.A., Haghighi, S.S., Adelstein, E.H. \& Madsen, R. (1996). The effects of taxol, methylprednisolone and 4-aminopyridine in compressive spinal cord injury: a qualitative experimental study. Surgical Neurology 46, 350-357.

43. Haghighi, S.S., Clapper, A., Johnson, G.C., Stevens, A. \& Prapaisilp, A. (1998). Effect of 4-aminopyridine and single-dose methylprednisolone on functional recovery after a chronic spinal cord injury. Spinal Cord 36, 6-12.

44. Haghighi, S.S., Agrawal, S.K., Surdell, D., Plambeck, R., Agrawal, S., Johnson, G.C. \& Walker, A. (2000). Effects of methylprednisolone and MK-801 on functional recovery after experimental chronic spinal cord injury. Spinal Cord 38, 733-740.

45. Hara, M., Takayasu, M., Watanabe, K., Noda, A., Takagi, T., Suzuki, Y. \& Yoshida, J. (2000). Protein kinase inhibition by fasudil hydrochloride promotes neurological recovery after spinal cord injury in rats. Journal of Neurosurgery 93, Suppl. 1, 94-101.

46. Legos, J.J., Gritman, K.R., Tuma, R.F. \& Young, W.F. (2001). Coadministration of methylprednisolone with hypertonic saline solution improves overall neurological function and survival rates in a chronic model of spinal cord injury. Neurosurgery 49, 1427-1433.

47. Nash, H.H., Borke, R.C. \& Anders, J.J. (2002). Ensheathing cells and methylprednisolone promote axonal regeneration and functional recovery in the lesioned adult rat spinal cord. Journal of Neuroscience 22, 7111-7120.

48. Rabchevsky, A.G., Fugaccia, I., Sullivan, P.G., Blades, D.A. \& Scheff, S.W. (2002). Efficacy of methylprednisolone therapy for the injured rat spinal cord. Journal of Neuroscience Research 68, $7-18$.

49. Lixin, L.I., Qiwu, X.U., Youzhang, W.U., Weixing, H.U., Peiyuan, G.U. \& Zhen, F.U. (2003). Combined therapy of methylprednisolone and brainderived neurotrophic factor promotes axonal regeneration and functional recovery after spinal cord injury in rats. Chinese Medical Journal 116, 414-418.

50. Yu, Y., Matsuyama, Y., Nakashima, S., Yanase, M., Kiuchi, K. \& Ishiguro, N. (2004). Effects of MPSS and a potent iNOS inhibitor on traumatic spinal cord injury. NeuroReport 15, 2103-2107.

51. Kim, D.H. \& Jahng, T-A. (2004). Continuous brain-derived neurotrophic factor (BDNF) infusion after methylprednisolone treatment in severe spinal cord injury. Journal of Korean Medical Science 19, 113-122.

52. Gorio, A., Madaschi, L., Di Stefano, B., Carelli, S., Di Giulio, A.M., Biasi, S., Coleman, T., Cerami, A. \& Brines, M. (2005). Methylprednisolone neutralizes the beneficial effects of erythropoietin in experimental spinal cord injury. Proceedings of the National Academy of Sciences of the USA 102, 16,379-16,384.

53. Lee, B.H., Lee, K.H., Yoon, D.H., Kim, U.J., Hwang, Y.S., Park, S.K., Choi, J.U. \& Park, Y.G. (2005). Effects of methylprednisolone on the neural conduction of the motor evoked potentials in spinal cord injured rats. Journal of Korean Medical Science 20, 
132-138.

54. Lopez-Vales, R., Guillermo, G-A., Fores, J., Udina, E., Gold, B.G., Navarro, X. \& Verdu, E. (2005). FK506 reduces tissue damage and prevents functional deficit after spinal cord injury in the rat. Journal of Neuroscience Research 81, 827-836.

55. Cetin, A., Nas, K., Buyukbayram, H., Ceviz, A. \& Olmez, G. (2006). The effects of systematically administered methylprednisolone and recombinant human erythropoietin after acute spinal cord compressive injury in rats. European Spine Journal 15, 1539-1544.

56. Zileli, M., Ovul, I. \& Dalbasti, T. (1988). Effects of methylprednisolone, dimethyl sulphoxide and naloxone in experimental spinal cord injuries in rats. Neurological Research 10, 232-235.

57. Cayli, S.R., Kocak, A., Yilmaz, U., Tekiner, A., Erbil, M., Ozturk, C., Batcioglu, K. \& Yologlu, S. (2004). Effect of combined treatment with melatonin and methylprednisolone on neurological recovery after experimental spinal cord injury. European Spine Journal 13, 724-732.

58. Cayli, S.R., Ates, O., Karadag, N., Altinoz, E., Yucel, N., Yologlu, S., Kocak, A. \& Cakir, C.O. (2006). Neuroprotective effect of etomidate on functional recovery in experimental spinal cord injury. International Journal of Developmental Neuroscience 24, 233-239.

59. Takami, T., Oudega, M., Bethea, J.R., Wood, P.M., Kleitman, N. \& Bunge, M.B. (2002). Methylprednisolone and interleukin-10 reduce gray matter damage in the contused Fischer rat thoracic spinal cord but do not improve functional outcome. Journal of Neurotrauma 19, 653-666.

60. Guizar-Sahagun, G., Grijalva, I., Salgado-Ceballos, H., Espitia, A., Orozco, S., Ibarra, A., Martinez, A., Franco-Bourland, R.E. \& Madrazo, I. (2004). Spontaneous and induced aberrant sprouting at the site of injury is irrelevant to motor function outcome in rats with spinal cord injury. Brain Research 1013, 143-151.

61. Mu, X., Azbill, R.D. \& Springer, J.E. (2000). Riluzole and methylprednisolone combined treatment improves functional recovery in traumatic spinal cord injury. Journal of Neurotrauma 17, 773-780.

62. Ji, B., Li, M., Budel, S., Pepinsky, B., Walus, L., Engber, T.M., Strittmatter, S.M. \& Relton, J.K. (2005). Effect of combined treatment with methylprednisolone and soluble Nogo-66 receptor after rat spinal cord injury. European Journal of Neuroscience 22, 587-594.

63. Guizar-Sahagun, G., Ibarra, A., Espitia, A., Martinez, A., Madrazo, I. \& Franco-Bourland, R.E. (2005). Glutathione monoethyl ester improves functional recovery, enhances neuron survival, and stabilizes spinal cord blood flow after spinal cord injury in rats. Neuroscience 130, 639-649.

64. Wells, J.E.A., Hurlbert, R.J., Fehlings, M.G. \& Yong, V.W. (2003). Neuroprotection by minocycline facilitates significant recovery from spinal cord injury in mice. Brain 126, 1628-1637.

65. Sheng, H., Spasojevic, I., Warner, D.S. \& BatinicHaberle, I. (2004). Mouse spinal cord compression injury is ameliorated by intrathecal cationic manganese (III) porphyrin catalytic antioxidant therapy. Neuroscience Letters 366, 220-225.

66. Anghelescu, N., Petrescu, A. \& Alexandrescu, I. (1995). Therapy study on the experimental injury of spinal cord IV. High doses of methylprednisolone. Romanian Journal of Neurology \& Psychiatry 33, 241-249.

67. Okonkwo, D.O., Reece, T.B., Laurent, J.J., Hawkins, A.S., Ellman, P.I., Linden, J., Kron, I.L., Tribble, C.G., Stone, J.R. \& Kern, J.A. (2006). A comparison of adenosine $\mathrm{A}_{2 \mathrm{~A}}$ agonism and methylprednisolone in attenuating neuronal damage and improving functional outcome after experimental traumatic spinal cord injury in rabbits. Journal of Neurosurgery. Spine 4, 64-70.

68. Means, E.D., Anderson, D.K., Waters, B.S. \& Kalaf, L. (1981). Effect of methylprednisolone in compression trauma to the feline spinal cord. Journal of Neurosurgery 55, 200-208.

69. Demopoulos, H.B., Flamm, E.S., Seligman, M.L., Pietronigro, D.D. \& De Crescito, V. (1982). Further studies on free-radical pathology in the major central nervous system disorders: effect of very high doses of methylprednisolone on the functional outcome, morphology, and chemistry of experimental spinal cord impact injury. Canadian Journal of Physiology \& Pharmacology 60, 14151424.

70. Faden, A.I., Jacobs, T.P., Patrick, D.H. \& Smith, M.T. (1984). Megadose corticosteroid therapy following experimental traumatic spinal injury. Journal of Neurosurgery 60, 712-717.

71. Anderson, D.K., Saunders, R.D., Demediuk, P., Dugan, L.L., Braughler, M., Hall, E.D., Means, E.D. \& Horrocks, L.A. (1985). Lipid hydrolysis and peroxidation in injured spinal cord: partial protection with methylprednisolone or vitamin $\mathrm{E}$ and selenium. Central Nervous System Trauma 2 , 257-267.

72. Braughler, J.M., Hall, E.D., Means, E.D., Waters, T.R. \& Anderson, D.K. (1987). Evaluation of an intensive methylprednisolone sodium succinate dosing regimen in experimental spinal cord injury. Journal of Neurosurgery 67, 102-105.

73. Young, W., De Crescito, V., Flamm, E.S., Blight, A.R. \& Gruner, J.A. (1988). Pharmacological therapy of acute spinal cord injury: studies of high dose methylprednisolone and naloxone. Clinical Neurosurgery 34, 675-697.

74. Ducker, T.B. \& Hamit, H.F. (1969). Experimental treatments of acute spinal cord injury. Journal of Neurosurgery 30, 693-697.

75. Coates, J.R., Sorjonen, D.C., Simpson, S.T., Cox, N.R., Wright, J.C., Hudson, J.A., Finn-Bodner, S.T. \& Brown, S.A. (1995). Clinicopathologic effects of a 21-aminosteroid compound (U74389G) and highdose methylprednisolone on spinal cord function after simulated spinal cord trauma. Veterinary Surgery 24, 128-139.

76. Yang, J., Jeong, S., Seo, K. \& Nam, T. (2003). Effects of corticosteroid and electroacupuncture on experimental spinal cord injury in dogs. Journal of Veterinary Science 4, 97-101.

77. Yeo, J.D., Payne, W., Hinwood, B. \& Kidman, A.D. (1975). The experimental contusion injury of the spinal cord in sheep. Paraplegia 12, 275-296.

78. Green, B.A., Kahn, T. \& Klose, K.J. (1980). A comparative study of steroid therapy in acute experimental spinal cord injury. Surgical Neurology 13, 91-97.

79. Young, W. (2002). Spinal cord contusion models. Progress in Brain Research 137, 231-255.

80. Werner, C., Möllenberg, O., Kochs, E. \& Schulte am 
Esch, J. (1995). Sevoflurane improves neurological outcome after incomplete cerebral ischaemia in rats. British Journal of Anaesthesia 75, 756-760.

81. Lopez, S., Privat, A., Bernard, N., Ohanna, F., Vergnes, C. \& Capdevila, X. (2004). Intrathecal bupivacaine protects against extension of lesions in an acute photochemical spinal cord injury model. Canadian Journal of Anaesthesia 51, 364-372.

82. Augustsson, H., Lindberg, L., Hoglund, A.U. \& Dahlborn, K. (2002). Human-animal interactions and animal welfare in conventionally and penhoused rats. Laboratory Animals 36, 271-281.

83. Balcombe, J.P., Barnard, N.D. \& Sandusky, C. (2004). Laboratory routines cause animal stress. Contemporary Topics in Laboratory Animal Sciences 43, 42-51.

84. Vallee, M., Mayo, W., Maccari, S., Le Moal, M. \& Simon, H. (1996). Long-term effects of prenatal stress and handling on metabolic parameters: relationship to corticosterone secretion response. Brain Research 712, 287-292.

85. Benefiel, A.C., Dong, W.K. \& Greenough, W.T. (2005). Mandatory "enriched" housing of laboratory animals: The need for evidence-based evaluation. Institute of Laboratory Animal Resources Journal 46, 95-105.

86. Krohn, T.C., Hansen, A.K. \& Dragsted, N. (2003). The impact of cage ventilation on rats housed in IVC systems. Laboratory Animals 37, 85-93.

87. Dobrossy, M.D. \& Dunnett, S.B. (2004). Environmental enrichment affects striatal graft morphology and functional recovery. European Journal of Neuroscience 19, 159-168.

88. Engesser-Cesar, C., Anderson, A.J., Basso, D.M., Edgerton, V.R. \& Cotman, C.W. (2005). Voluntary wheel running improves recovery from a moderate spinal cord injury. Journal of Neurotrauma 22, 157-171.

89. Lankhorst, A.J., ter Laak, M.P., van Laar, T.J., van Meeteren, N.L.U., de Groot, J.C.M.J., Schrama, L.H., Hamers, F.P. \& Gisoen, W.H. (2001). Effects of enriched housing on functional recovery after spinal cord contusive injury in the adult rat. Journal of Neurotrauma 18, 203-215.

90. Van Loo, P.L.P., Van der Meer, E., Kruitwagen, C.L.J.J., Koolhaas, J.M., Van Zutphen, L.F.M. \& Baumans, V. (2004). Long-term effects of husbandry procedures on stress-related parameters in male mice of two strains. Laboratory Animals 38, 169-177.

91. Rabchevsky, A.G. \& Smith, G.M. (2001). Therapeutic interventions following mammalian spinal cord injury. Archives of Neurology 58, 721-726.

92. Rosenzweig, E.S. \& McDonald, J.W. (2004). Rodent models for treatment of spinal cord injury: research trends and progress toward useful repair. Current Opinion in Neurology 17, 121-131.

93. Stoke, B.T. \& Jakeman, L.B. (2002). Experimental modeling of human spinal cord injury: a model that crosses the species barrier and mimics the spectrum of human cytopathology. Spinal Cord 40, 101-109.

94. Kwon, B.K., Oxland, T.R. \& Tetzlaff, W. (2002). Animal models used in spinal cord regeneration research. Spine 27, 1504-1510.

95. Chesler, E.J., Wilson, S.G., Lariviere, W.R., Rodriguez-Zas, S.L. \& Mogil, J.S. (2002). Identification and ranking of genetic and laboratory environment factors influencing a behavioral trait, thermal nociception, via computational analysis of a large data archive. Neuroscience \& Biobehavioral Reviews 26, 907-923.

96. Crabbe, J.C., Wahlsten, D. \& Dudek, B.C. (1999). Genetics of mouse behavior: interactions with laboratory environment. Science 284, 1670-1672.

97. Guth, L., Zhang, Z. \& Steward, O. (1999). The unique histopathological responses of the injured spinal cord. Implications for neuroprotective therapy. Annals of the New York Academy of Sciences 890, 366-384.

98. Inman, D.M. \& Steward, O. (2003). Physical size does not determine the unique histopathological response seen in the injured mouse spinal cord. Journal of Neurotrauma 20, 33-42.

99. De La Torre, J.C. (1984). Spinal cord injury models. Progress in Neurobiology 22, 289-344.

100. Committee on Spinal Cord Injury (2005). Tools for assessing spinal cord injury and repair. In Spinal Cord Injury: Progress, Promise and Priorities. (ed. C.T. Liverman, B.M. Altevogt, J.E. Joy \& R.T. Johnson), pp. 64-94. Washington, DC, USA: The National Academies Press. Available at: http:// www.iom.edu/CMS/3775/14986/26196.aspx (Accessed 14.01.09)

101. Popovich, P.G., Wei, P. \& Stokes, B.T. (1997). Cellular inflammatory response after spinal cord injury in Sprague-Dawley and Lewis rats. The Journal of Comparative Neurology 377, 443-464.

102. Sroga, J.M., Jones, T.B., Kigerl, K.A., McGaughy, V.M. \& Popovich, P.G. (2003). Rats and mice exhibit distinct inflammatory reactions after spinal cord injury. The Journal of Comparative Neurology 462, 223-240.

103. Akhtar, A., Pippin, J. \& Sandusky, C. (2008). Animal models in spinal cord injury: A review. Reviews in the Neurosciences 19, 47-60.

104. Kakulas, B.A. (1999). The applied neuropathology of human spinal cord injury. Spinal Cord 37, 79-88.

105. Tom, V.J., Steinmetz, M.P., Miller, J.H., Doller, C.M. \& Silver, J. (2004). Studies on the development and behavior of the dystrophic growth cone, the hallmark of regeneration failure, and an in vitro model of the glial scar after spinal cord injury. The Journal of Neuroscience 24, 6531-6539.

106. Fayaz, I. \& Tator, C.H. (2000). Modeling axonal injury in vitro: injury and regeneration following acute neuritic trauma. Journal of Neuroscience Methods 102, 69-79.

107. Woolfe, F., Waxman, S.G. \& Hains, B.C. (2007). In silico modeling of axonal reconnection within a discrete fiber tract after spinal cord injury. Journal of Neurotrauma 24, 421-432.

108. Lucas, J.H., Gross, G.W., Emery, D.G. \& Gardner, C.R. (1985). Neuronal survival or death after dendrite transection close to the perikaryon: correlation with electrophysiologic, morphologic, and ultrastructural changes. CNS Trauma 2, 231-255.

109. Raghupathi, R., Grants, I., Rosenberg, L.J., McIntosh, T.K. \& Lucas, J.H. (1998). Increased jun immunoreactivity in an in vitro model of mammalian spinal neuron physical injury. Journal of Neurotrauma 15, 555-561.

110. Krassioukov, A.V., Ackery, A., Schwartz, G., Adamchik, Y., Liu, Y. \& Fehlings, M.G. (2002). An in vitro model of neurotrauma in organotype spinal cord cultures from adult mice. Brain Research Protocols 10, 60-68. 
111. Ellis, E.F., McKinney, J.S., Willoughby, K.A., Liang, S. \& Povlishock, J.T. (1995). A new model for rapid stretch-induced injury of cells in culture: characterization of the model using astrocytes. Journal of Neurotrauma 12, 325-339.

112. Regan, R.F. \& Panter, S.S. (1995). Traumatic neuronal injury in cortical cell culture is attenuated by 21-aminosteroids. Brain Research 682, 144150.

113. Li, R., Thode, S., Zhou, J., Richard, N., Pardinas, J., Rao, M.S. \& Sah, D.W. (2000). Motoneuron differen- tiation of immortalized human spinal cord cell lines. Journal of Neuroscience Research 59, 342-352.

114. Raymon, H.K., Thode, S., Zhou, J., Friedman, G.C., Pardinas, J.R., Barrere, C., Johnson, R.M. \& Sah, D.W. (1999). Immortalized human dorsal root ganglion cells differentiate into neurons with nociceptive properties. The Journal of Neuroscience 19, 5420-5428.

115. The Miami Project to Cure Paralysis. Available at: http://www.miamiproject.miami.edu/x350.xml (Accessed 29.02.08). 